園学雑. (J. Japan. Soc. Hort. Sci.) 62 (1)：207-213. 1993.

\title{
リンゴ‘スターキング・デリシャス’果実の食味保持と 揮発性成分生成に及ぼすポリエチレン包装の影響
}

\author{
上田悦範 ${ }^{1} \cdot$ 白 $\quad$ 晋和 ${ }^{*}$. 吉岡博人 ${ }^{2}$ \\ ${ }^{1}$ 大阪府立大学䄽学部 593 堺市学園町 1-1 \\ 2 果樹試験場盛岡支場 $020-01$ 盛岡市下厨川字鍋屋敷
}

Effects of Polyethylene Packaging on Flavor Retention and Volatile Production of 'Starking Delicious' Apple

Yoshinori Ueda ${ }^{1}$, Jin-He Bai ${ }^{1}$ and Hiroto Yoshioka ${ }^{2}$

${ }^{I}$ College of Agriculture, University of Osaka Prefecture, Sakai, Osaka 593

${ }_{2}^{2}$ Morioka Branch, Frit Tree Research Station, Shimokuriyagawa, Morioka 020-01

\begin{abstract}
Summary
'Starking Delicious' apple fruit (Malus domestica Borkh.) were packaged hermetically in low density polyethylene bags of 30 and $50 \mu \mathrm{m}$ thicknesses, and stored for 11 weeks at $8^{\circ} \mathrm{C}$. Oxygen concentrations in 30 and $50 \mu \mathrm{m}$ thick bags ranged from $12 \sim 15 \%$ and $5 \sim$ $9 \%$; carbon dioxide concentrations $4 \%$ and $5 \sim 6 \%$, respectively. The polyethylene packaging inhibited carbon dioxide and ethylene evolution. Softening of apples in 30 and 50 $\mu \mathrm{m}$ thick bags was retarded 2 and 4 weeks, respectively, compared with the fruits in perforated bags.

The characteristic volatiles of apple, such as butyl acetate and 2-methylbutyl acetate were produced at the beginning of storage. In perforated bags, the production of these esters was high on early period of the storage. But, as senescence of the fruit proceeded, ethyl alcohol and ethyl esters became the dominant volatiles.

In the $50 \mu \mathrm{m}$ thick package, the production of ethyl alcohol and ethyl estars, which are non-characteristic aromatic compounds for apple, was enhanced shortly after packaging; whereas production of butyl acetate and 2-methylbutyl acetate was decreased. These changes in the production of aromatic compounds resulted in an off-flavor.

In the $30 \mu \mathrm{m}$ thick package, the production of butyl acetate and 2-methylbutyl acetate was slightly inhibited, whereas ethyl alcohol and the esters were low during storage.
\end{abstract}

\section{緒言}

通気性を有する低密度ポリエチレンフィルムによる 青果物の密封包装は，青果物の呼吸によって包装袋内 が適度に低濃度酸素ならびに高濃度炭酸ガスのガス条 件となることから，簡便に Modified atomosphere (MA) 眝蔵の効果を得ることが期待できる. しかし, ポリエチレンフィルムの厚さによってガスの透過性が 異なるため，青果物の種類に合わせて適切なフィルム を選定しないと, ガス環境の恋化が少な過ぎて密封包

1992年 7 月14日 受理.

*現在：財団法人大阪環境事業経営管理協会.
装の効果がなかったり，過度となって生理的障害を誘 発するおそれがある(岡本ら，1962）。

青果物の包装に関する従来の研究は鮮度保持技術へ の利用が主で，果実の品質要因として極めて重要な芳 香についての研究例は少ない. Controlled atomosphere (CA) 貯蔵により，果実の特徵的な香りが減少 したり (Lidster ら, 1981，1983), オフフレーバーが 発生することがみられ (Anderson, 1967 ; Blanpied ら，1968）。ま，ポリエチレン包装によって果実に 異臭を生じるという報告があるが（岡本ら，1962； Liu，1978），芳香に寄与する揮発性成分の動向や，そ の变化の原因を追跡した報告はほとんどない。本研究 
は，ポリエチレン包装貯蔵のリンゴ果実の食味に対す る影響を調べるとともに，特に香気成分に着目し，環 境ガス条件が揮発性成分の生成に及ほす影響を検討し た。

\section{材料および方法}

\section{1.実験材料および貯葴方法}

実験に使用したリンゴ果実は，果樹試験場盛岡支場 で栽培された、スターキング・デリシャズである。 1988 年 10 月 30 日収穫し, その翌日大阪府立大学宛 に宅配運送した，発送 3 日後に研究室に到着し，その 後 $8^{\circ} \mathrm{C}$ に貯蔵した. 以降の貯蔵温度としては $8^{\circ} \mathrm{C}$ 選んだが, これは実際の冷蔵眝蔵温度でなく，流通最 終段階のスーパーや小売店での室内冷却棚温度の平均 温度程度と考えた，果実の収穫は通常の収穫期よりや や遅れていたこともあって，研究室到着後，十数個の 切断検查によって果実の半数には“みつ”が生じてい ることがわかった，到着の翌日，低密度ポリエチレン 袋 $(260 \times 380 \mathrm{~mm})$ に1 袋当たり果実 4 個ずつを包装 して，次の 3 区を設けた。 1 ，有孔包装区（厚さ 30 $\mu \mathrm{m}$, 直径 $5 \mathrm{~mm}$ 穴 100 個, 開孔率約 $1 \%$ 以下有孔区 と略す)，2，厚さ $30 \mu \mathrm{m}$ の低密度ポリエチレン袋密 封包装区（以下薄手区）。，厚さ50 $\mu \mathrm{m}$ の低密度ポ リエチレン袋密封包装区（以下厚手区）。また有孔区， 包装区とも分析日当たり 3 袋を用意した，袋内ガスお よび成分の測定は眝蔵期間中（11 週間），週ごとに行 った，すべての測定值は 3 袋の平均値である.

2. 果肉硬度, 遊離酸および可溶性固形物含 量の測定

EFFEGI の FT 327 型 Penetrometer で果肉硬度を測 定した，果実を剝皮し赤道面を 3 か所測定しその平均 値で表した。プランジャーの直径は $1 \mathrm{~cm}$ であった。 単位はポンド（Lb）目盛りを読み取った。

遊離酸については，果実の可食部を乳鉢ですりつぶ し，ガーゼ 2 重で搾って果汁を得て，その $10 \mathrm{ml}$ 用 いて, $0.1 \mathrm{~N} \mathrm{NaOH} て ゙$ 滴定し，リンゴ酸として換算し た。

可溶性固形物含量は屈折糖度計で上記果汁を測定し Brix の度数で示した.

3.ポリエチレン包装による袋内酸素, 炭酸 ガスおよびェチレン濃度の測定

袋内ガス分析は冷蔵庫 $\left(8^{\circ} \mathrm{C}\right)$ に眝蔵している状態 のままで $1 \mathrm{~m} l$ を採取して, ガスクロマトグラフィー （GC）で分析した，GC装置はYanaco G 80，酸素測 定用カラムは Molecular sieve 5A (2 $\mathrm{m} \times 3 \mathrm{~mm}$ 内径),
炭酸ガス測定用カラムは Porapak Q $(2 \mathrm{~m} \times 3 \mathrm{~mm})$, エチレン測定用カラムは活性アルミナ $(1 \mathrm{~m} \times 3 \mathrm{~mm})$, キャリヤーガスは $\mathrm{He}\left(40 \mathrm{ml} \cdot \mathrm{min}^{-1}\right)$ を用い,カラ 么温度は $60^{\circ} \mathrm{C}$ として測定した．検出器として酸素と 炭酸ガスは TCD，エチレンはFID を用いた。

\section{4. ポリエチレン包装貯蔵後における果実の揮発性成}

\section{分生成量の測定}

貯蔵リンゴを袋内から取出し， $20{ }^{\circ} \mathrm{C}$ で 6 時間放置 した後，3個体を半割し，それぞれの半分（350〜400 g）を供試した。をれを $1,250 \mathrm{ml}$ デシケータ一内に 30 分間密封後,ヘッドスペース気体を注射器で $5 \mathrm{ml}$ 採取し，GCで測定した。デシケーターは各区 3 個用 意した. カラムは $P G 9000(1 \mathrm{~m} \times 3 \mathrm{~mm}$, 内径) で, 昇温 $\left(60^{\circ} \mathrm{C} \rightarrow 120^{\circ} \mathrm{C}, 4{ }^{\circ} \mathrm{C} \cdot \mathrm{min}^{-1}\right)$ により測定した。 キャリヤーガスは窒素 $\left(40 \mathrm{ml} \cdot \min ^{-1}\right)$, 検出器は FID 老用いた。

5. 貯蔵果実の炭酸ガス排出量およびエチ レン生成量の測定

上記揮発性成分測定用のデシケーター中の炭酸ガス, エチレン量を測ることにより，果実の炭酸ガス排出量， エチレン生成量を算出した。密封 30 分後に，各区 3 個のデシケーターよりヘッドスペースの気体を $1 \mathrm{ml}$, 各々 2 本を採取し，GCで炭酸ガス排出量およびエチ レン生成量を測定した。この測定ではリンゴを半割に した場合の炭酸ガス，エチレンの生成量をみているが, 以前の CA 貯蔵の実験に扔いて (未発表)，果実を半 割すると個体レベルの炭酸ガス，エチレンの生成量に 比べ 2 倍一 2 倍半の生成量があった。しかし熟度が違 ってもその比率は変わらなかったので，リンゴを半割 して測定したことを明示して炭酸ガス，エチレン生成 量とした.

\section{結果および考察}

1.ポリエチレン包装による袋内酸素, 炭酸 ガスおよびエチレン濃度の变化

$8^{\circ} \mathrm{C}$ 貯蔵中におけるポリエチレン包装内の酸素濃度 は薄手区，厚手区とも隇少した後やや上昇する傾向が みられたものの，薄手区は $12 \sim 15 \%$ ，厚手区は 5 $9 \%$ 範囲で推移した，袋内炭酸ガス濃度は薄手区が $4 \%$ 前後，厚手区が5－6\%であった．袋内エチレン濃 度は薄手区と厚手区とも貯蔵につれて増加し, 最大値 は $400 \mathrm{ppm}$ を超えた(第 1 図).

\section{2. 果実の炭酸ガス排出量およびエチレン 生成量}

第 2 図に示すように有孔区の炭酸ガス排出量は眝藏 


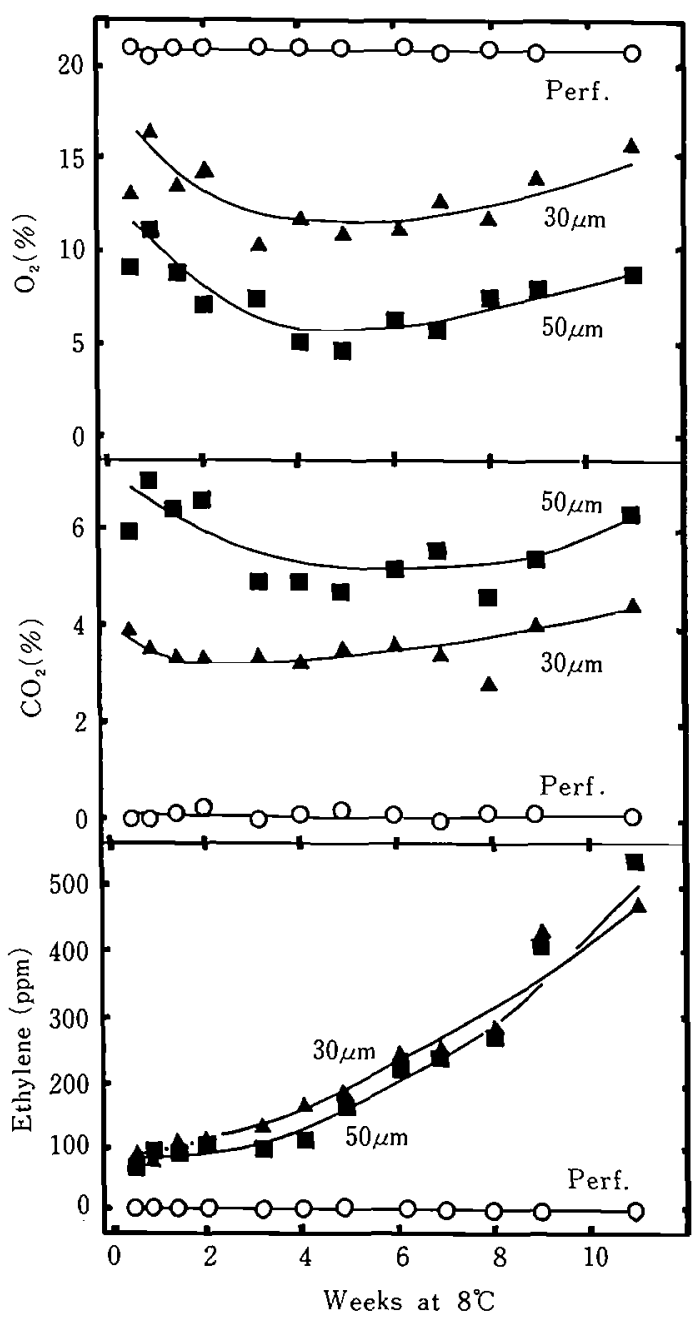

Fig. 1. Oxygen (upper section), carbon dioxide (middle), and ethylene (bottom) concentrations in polyethylene bags during storage at $8^{\circ} \mathrm{C}$.

A. $30 \mu \mathrm{m}$ thick bags; $\mathbf{0}, 50 \mu \mathrm{m}$ thick bags; $\bigcirc$. Perforated bags.

4 週頃まで顕著に增大し，炭酸ガス生成のピークはほ ほ眝藏 4〜6週後に現れた。これはクライマクテリッ ク・マキシマムと考えられる，厚手区では貯蔵 8 週ま で呼吸の増大を抑制したが，9週以降に炭酸ガス生成 が急増した．薄手区は両者の中間的な変化傾向であっ たがやはり 9 週以後に顕著に増大した。

エチレン生成量は有孔区が明らかにクライマクテリ ック・ライズの型を示したが, 生成のピークは炭酸ガ スのピークより約 1〜2 週間遅く，眝蔵 7 週頃に出現 した，両密封区は密封によりただちにエチレンの生成

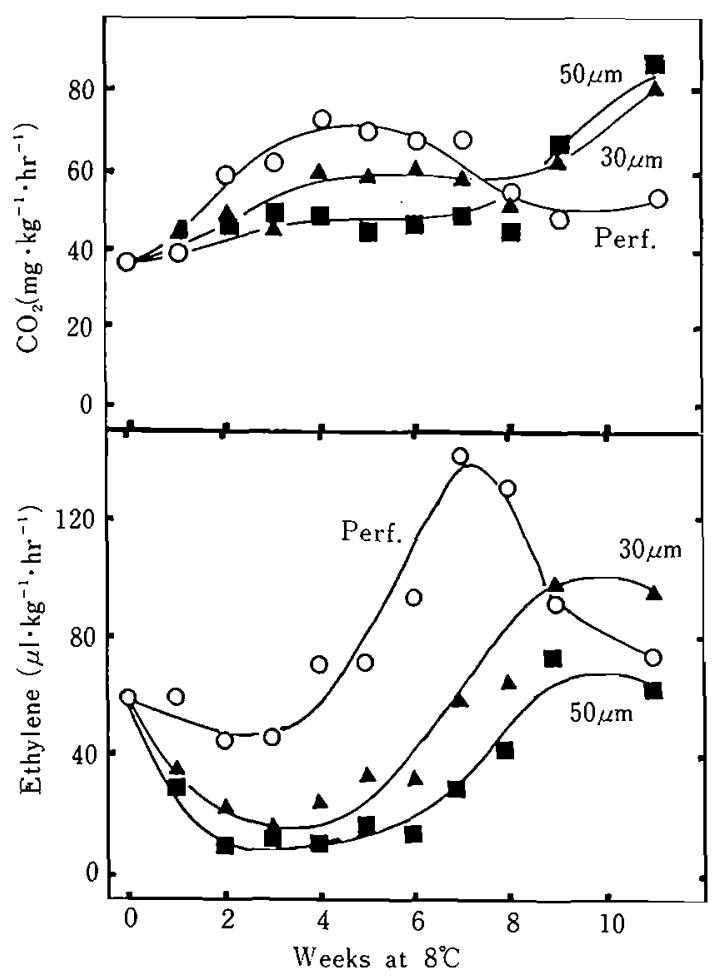

Fig. 2. Carbon dioxide (upper) and ethylene production (lower) of apple fruit held at $20^{\circ} \mathrm{C}$ for $6 \mathrm{hr}$ after removal from $8^{\circ} \mathrm{C}$ room. The halved apples were incu. bated for $30 \mathrm{~min}$ at $20^{\circ} \mathrm{C}$ in a jar after which the headspace gas was analyzed.

$\boldsymbol{\Lambda}$. $30 \mu \mathrm{m}$ thick bags; $\mathbf{D}, 50 \mu \mathrm{m}$ thick bags; $\bigcirc$, Perforated bags.

が低下したが，5週以降に急增し，眝蔵 10 週前後が ピークとなった．密封区のエチレンのピーク值は有孔 区より低く，厚手区は薄手区より低かった（第 2 図）。 これは包装内の酸素濃度および炭酸ガス濃度の蓄積の 程度と対応しており，厚手区のエチレン生成は薄手区 より抑制された。

3. 果肉硬度, 遊離酸含量および可溶性固形 物含量の変化

果肉硬度は眝蔵につれて低くなったが，ほほ10ポ ンド以下になると食味が低下し硬度上の品質限界にな ると考えられた，有孔区は眝蔵 4 週でこの限界以下に なったのに対して，薄手区と厚手区はそれぞれ 6 週と 8 週まで維持された（第 3 図）．リンゴの食味の指標 は一般に糖，酸および果肉硬度で表される，上記の因 子であらわされる食味保持に対してはポリエチレン包 


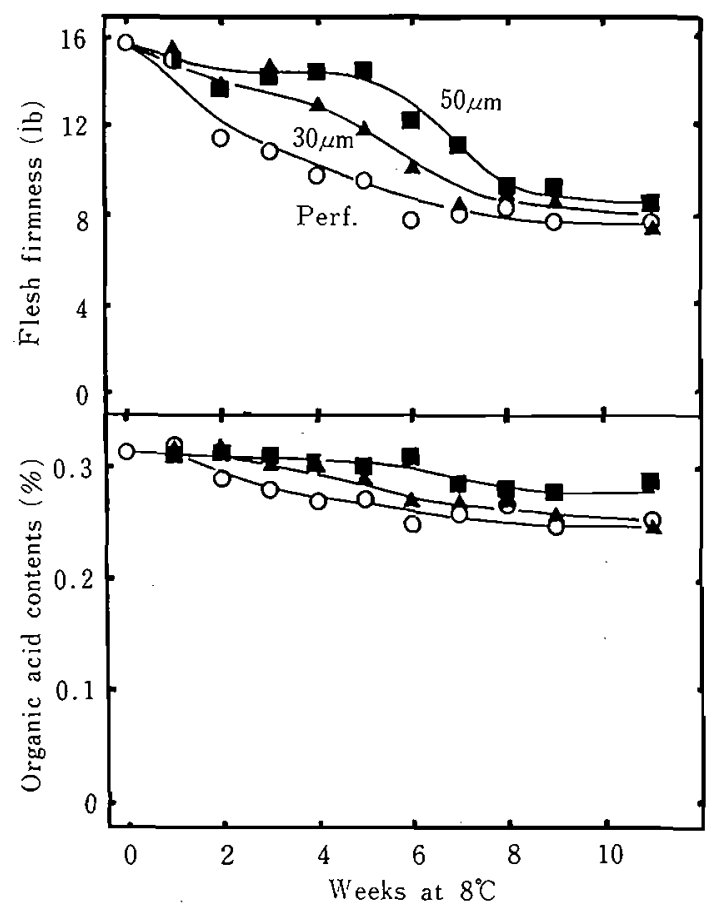

Fig. 3. Effect of polyethylene packaging on changes of flesh firmness (upper) and organic acids contents (lower) of apples stored at $8^{\circ} \mathrm{C}$.

A, $30 \mu \mathrm{m}$ thick bags; $\mathbf{\square}, 50 \mu \mathrm{m}$ thick bags; $\mathrm{O}$, Perforated bags.

装は有効であるといういくつかの研究報告がみられる (岡本ら，1961；白ら，1989). 本研究においても，厚 己 $30 \mu \mathrm{m}$ (薄手区) $50 \mu \mathrm{m}$ のポリエチレン包装（厚手 区）とも果肉硬度保持に対する効果が明らかで，ポリ エチレン包装により良好な食味保持の期間を延長する ことができた。

貯蔵中，果肉の遊離酸含量は，いずれの処理区も減 少の傾向がみられたが，やはり有孔区は最も速く，厚 手区は遅かった（第 3 図）。しかし，pHはいずれの処 理区も約 3.8 4.0で，貯蔵中の変化は少なかった (デー夕省略).

果実の可溶性固形物含量は約 $13^{\circ} \mathrm{Brix}$ でいずれの処 理区も貯蔵中あまり変化しなかった（データ省略）.

\section{4.ポリエチレン包装貯蔵後における揮発}

\section{性成分生成の変化}

第 4 図は貯藏当初の揮発性成分のガスクロマトグラ ムを示している．ピーク番号の化学物質名は標品との リテンションタイムの比較によって推定した。 このな かから香りおよびオフフレーバーに関与すると思われ

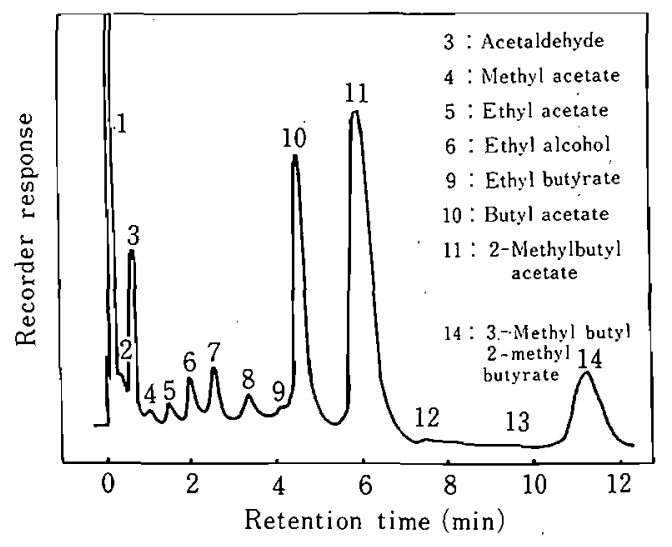

Fig. 4. A chromatogram of headspace volatiles from 'Starking Delicious' apple at the beginning of stor. age. Halved apples were incubated for $30 \mathrm{~min}$ at $20^{\circ} \mathrm{C}$ in a jar.

る代表的な揮発性成分のいくつかを対象として，その 変化傾向を第 5,6 図に示した.

1) ブチルアセテート，2-メチルブチルアセテート : リンゴの特徴的な香気にブチルアセテートや2-メ チルブチルアセテートなどのエステルが寄与している ことが報告されている（林・矢島，1980； Mattheisら， 1991 b)，上記エステル類は眝蔵前の果実においてか なりの量が生成されており，すでに良好な香気を有し ていた，有孔区では両エステルの生成㘹はさらに貯蔵 5〜6 週まで上昇し，以後減少した。有孔区は盯蔵初 期には硬度もあり香気も上昇するので食味は良好であ った，両密封区は始めその生成を抑制したが，後期に 漸次増加し，末期に有孔区を超えた。この間やや厚手 区の方が薄手区より抑制程度が強かった（第 5 図）。 このようにポリエチレン包装により貯藏初期に香気生 成が抑制されるのは果実の食味の点からは好ましくな いと考えられる．有孔区に㧍けるこれらのエステルの 急激な増加や両密封区の 4 週以降の增加は果肉硬度の 低下と平行していた。したがって果肉の細胞がルーズ になることがエステル香気の生成に都合がよいようで あったが, 貯蔵が長くなり, 果肉硬度の品質限界以下 になったときに、リンゴ特有の香気が增大しても実用 上意味のないことと考えられる。この二つのエステル の他にも同様に变化をするピークが2ー3みられた。

2) エチルアルコール：厚手区では密封包装後，エ チルアルコールが大量に生成した。しかし，販蔵が進 


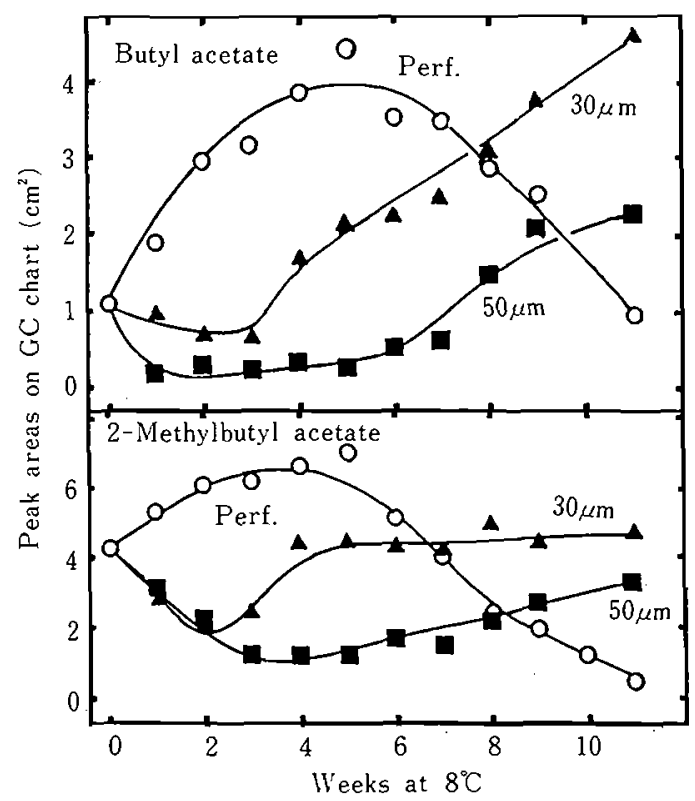

Fig. 5. Butyl acetate (upper) and 2-methylbutyl acetate (lower) in halved apple fruit treated as in Fig. 2.

$\boldsymbol{\Delta}, 30 \mu \mathrm{m}$ thick bags; $\square, 50 \mu \mathrm{m}$ thick bags; $\bigcirc$, Perforated bags.

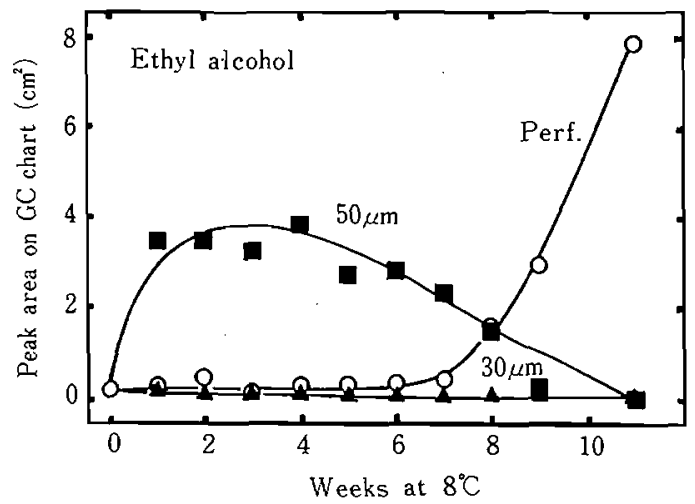

Fig. 6. Ethyl alcohol production in apple fruit treated as in Fig. 2.

A. $30 \mu \mathrm{m}$ thick bags; $\square .50 \mu \mathrm{m}$ thick bags; $\bigcirc$, Perforated bags.

をと急速に減少した，一方，有孔区では眝蔵初期には ほとんど生成しなかったが，眝蔵が進み果肉の軟化が 進むとともに急増した，薄手区では全貯蔵期間中その 生成がほとんどみられなかった（第 6 四）。厚手区の 酸素濃度は 5 9\%程度で，この包装袋の大きさ（260

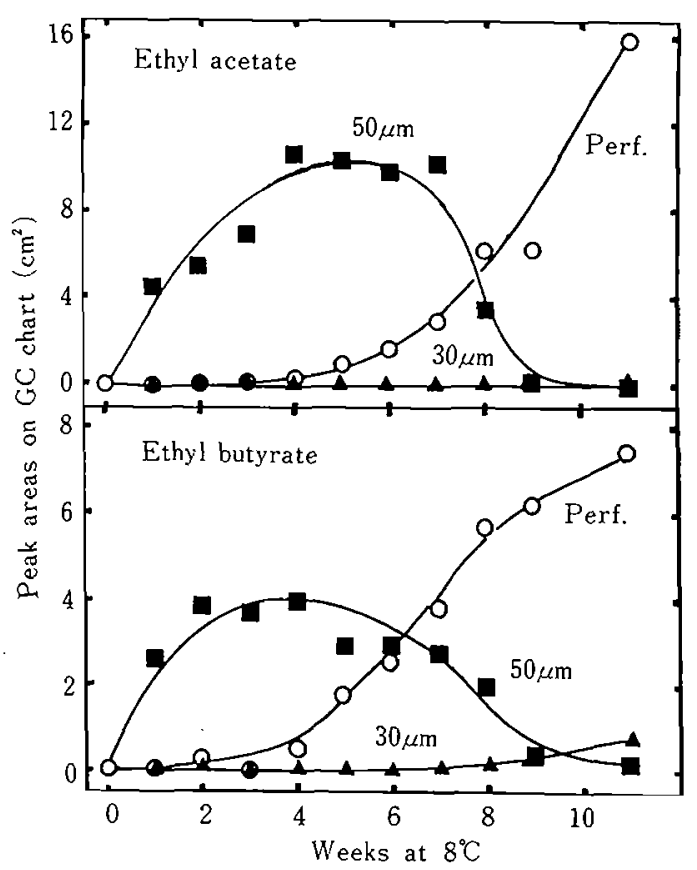

Fig. 7. Ethyl acetate (upper) and ethyl butyrate (lower) in apple fruit treated as in Fig. 2.

A. $30 \mu \mathrm{m}$ thick bags; $\square, 50 \mu \mathrm{m}$ thick bags; $\bigcirc$. Perforated bags.

$\times 380 \mathrm{~mm}$ )および封入個数（4 個）では酸素濃度 $1 \%$ 以下のような植物組織に対して一般的にいわれる嫌気 条件にならなかったことが明らかであった（第 1 図）。 また，果実空隙中の酸素濃度は袋内と比べて，ほとん ど同じか，わずかに低い程度であることはすでに報告 した (白ら，1990)。したがって厚手区での貯蔵初期 でみられるアルコール生成は炭酸ガス蓄積（5６\%） による嫌気呼吸と考えられる。 また有孔区の貯蔵後期 でみられるアルコール生成は, 外界のガス組成に関係 なく，果実老化に伴なう代謝系変動による（岡本， 1961）と考えられる.

3）エチルアセテートおよびエチルブチレート：エ チル系エステルとして，その生成量の变動はエチルア ルコールの消長とよく一致した。この結果は嫌気的な ガス条件をリンゴに与えた Mattheisら（1991 a) の結 果と一致した。すなわち，厚手区では前期で大量に生 成，眝蔵が進むにつれて急速に減少した，有孔区では 販蔵初期にはほとんど生成せず，後期に急増した。薄 手区では全貯蔵期間中生成がほとんどみられなかった (第 7 図). 
厚手区の販蔵初期および有孔区の後期に大量に生成 したエチル系エステルはリンゴの香気とは異なった香 りを有した。これらのエステルと，同時に生成するエ チルアルコールは本来は果実芳香成分の一部分である が, 多量またはアンバランスに蓄積すれば，異臭を呈 すると思われる。

薄手区は対照の有孔区に比べてリンゴの特徵的な香 気成分の生成は少し㧕制されたが，エチルアルコール およびエチル系エステルの大量生成は起こらなかった。 また果肉の硬度の保持などがみられるので，小売段階 での食味保持には髟れていると思われる.

また，両包装区の揮発性成分生成に対する相違は， 嫌気呼吸を起こす環境ガス濃度の範囲と追熟を抑制し， 硬度を保持するガス籁围が明確に区別できることを示 している.

以上通常の流通・小売段階での棚温度として考えた $8^{\circ} \mathrm{C}$ 貯蔵でのスターキング・デリシャスの低密度ポリ エチレン密封，小袋包装では，硬度・酸度の保持には 厚手区 $(50 \mu \mathrm{m})$ のフイルムが優れていたが，エチル アルコール等が蓄積し異臭が感じられた。薄手区(30 $\mu \mathrm{m})$ はリンゴの香気がやや減少するもののエチルア ルコールなどの蓄積もなく, 有孔区に比べ果肉硬度の 低下は約 2 週遅れ，食味は優れていた．勿論，50 $\mu \mathrm{m}$ の厚手区がリンゴのアルコール生成を促し，包装に不

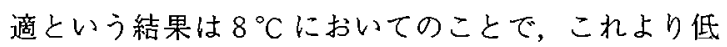
い温度で行う普通冷蔵眝蔵ではアルコールの生成は起 こらないものと考えられる，神戸ら（1975）は袋の大 きさ，収納するリンゴの量により品質保持に違いが出 ることを報告しているが，同温度においても包装形態 が違えばリンゴの香気成分も当然影響を受けると考之 られる。したがってその基礎になる緟密な温度，ガス 条件と異臭の原因物質であるエチルアルコールの生成 ・代謝との関係，さらには果実の老化との関係を調べ る必要があろう。

\section{摘 要}

岩手県産リンゴ・スターキング・デリシャス’を大阪 に常温輸送後直ちに低密度ポリエチレン袋で密封包装 し， $8{ }^{\circ} \mathrm{C} て ゙ 11$ 週間貯蔵した。 ポリエチレン袋は厚さ $30 \mu \mathrm{m}$ （薄手区）拉よび50 $\mu \mathrm{m}$ （厚手区）を用いた。 また対照として，有孔包装 $(30 \mu \mathrm{m}$ ，開孔率約 1\%) も設けた，密封包装により，酸素濃度は薄手区で 12 〜 15\%，愿手区で5〜9\%になり炭酸ガス濃度は薄手

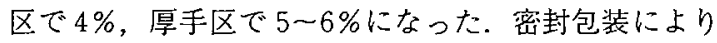
袋内は低酸素, 高炭酸ガス条件となり, 果実の呼吸量
およびエチレン生成量は有孔区より抑制された。果肉 の軟化も有孔区に比へ薄手区で 2 週, 厚手区で 4 週程 度遅れた。

ブチルアセテートや 2-メチルブチルアセテートな どのリンゴ香気に寄与する揮発性成分は貯蔵開始時に も生成量がかなりあった。

有孔包装では賋蔵後も増加し, 貯蔵後 5 週で最高值 になった，その後果実の老化が進むとともに，エチル アルコール拉よびそのエステルの生成が急増した。

厚手区では䝪蔵中，ブチルアセテート，2-メチルブ チルアセテートの生成が抑制され，またただちにエチ ルアルコールおよびエチルエステルが大量に生成し,

異臭と感じられた。

一方, 薄手区では上記リンゴの香気に寄与する両工 ステルの生成がやや抑制されたが，エチルアルコール， エチルエステルの生成は低レベルを保った．

謝辞本研究を遂行するに当たり, 御指導, 御 助言を賜った大阪府立大学農学部名誉教授 岩田隆氏 および園芸利用学研究室教授 茶珍和雄氏に対して深 謝の意を表します。

\section{引用文献}

Anderson, R. E. 1967. Experimental storage of eastern-grown 'Delicious' apples in various controlled atmospheres. Proc. Amer. Soc. Hort. Sci. 91 : 810-820.

白 晋和・阿部一博·岩田 隆・橋本 正・森田昭彦. 1989。細菌利用エチレン除去剤によるCA 出庫り ンゴの品質保持. 日食低温誌. $15: 119-125$.

白 晋和・ 上田悦範・岩田 隆・吉岡博人. 1990. ポ リエチレン包装がリンゴ果実の揮発性成分生成に 及ほす影響一一とくに果実内ガス濃度との関係に ついて. 園学雑. 59 (別冊 2) : 714-715.

Blanpied, G. D., R. M. Smock and L. C. Frank. 1968. Some factors influencing the ethanol content of harvested apple fruits. Proc. Amer. Soc. Hort. Sci. $92: 748-754$.

林 和夫・矢島 泉. 1980 . 食品のフレーバー成分. p. 139-140. 藤巻正生・服部達彦・林 和夫 - 荒 井綜一編. 香料の辞典. 朝倉書店. 東京.

神戸和猛登・今喜代治・久米靖穂・田口辰雄. 1975 リンゴ果実のポリエチレン包装による鮮度保持。 秋田県果樹試研報. $7: 1-34$

Lidster, P. D., K. B. McRae and K. A. Sanford. 1981. Responses of 'McIntosh' apples to low oxygen storage. J. Amer. Soc. Hort. Sci. 106 : 159-162.

Lidster, P. D., H. J. Lightfoot and K. B. McRae. 1983. Production and regeneration of principal volatiles in apples stored in modified atmospheres and air. J. Food Sci. $48: 400-405$.

Liu, F. W. 1978. Ripening bananas with ethephon in 
three polymeric film packages. HortScience 13 : 688-690.

Mattheis, J. P., D. A. Buchanan and J. K. Fellman. 1991a. Changes in apple fruit volatiles after storage in atmospheres inducing anaerobic metabolism. J. Agric. Food Chem. 39: 1602-1605.

Mattheis, J. P., J. K. Fellman, P. M. Chen and M. E. Patterson. 1991 b. Changes in headspace volatiles during physiological development of Bisbee Delicious apple fruit. J. Agric. Food Chem. 39 :
1902-1906.

岡本長夫. 1961. 販蔵リンゴの生化学的研究 (第 3 報）リンゴ酸の代謝. 農化. $35: 1355-1360$

阊本辰夫・堀津圭祐・原田順厚. 1961.リンゴ果実の ポリエチレン袋による貯蔵について．弘前大学農 研報. $7: 23-28$.

岡本辰夫・堀津圭祐・原田順厚. 1962. リンゴ果実の ポリエチレン袋による睆蔵について（第 2 報） 弘前大学丵研報. $8: 29-33$. 